\title{
Shadow Economies in OECD Countries: DGE vs. MIMIC Approaches
}

\section{Ceyhun Elgin*}

Boğaziçi University

\author{
Friedrich Schneider** \\ Johannes Kepler University of Linz
}

\begin{abstract}
In this paper we compare the levels and driving forces of shadow economies in 38 OECD countries using two different methodologies. One of these methods is the multipleindicators-multiple-causes (MIMIC) approach based on an estimation of a structural equation model. The other one is based on a two-sector dynamic general equilibrium (DGE) model developed by Elgin and Oztunali (2012). According to our results, the average driving forces of the shadow economy of the 38 OECD countries obtained using the MIMIC model show that personal income tax (13.8\%), indirect taxes (14.1\%), tax morale (14.5\%), unemployment (14.7\%), self-employment (14.5\%), growth of GDP (14.3\%) and business freedom index (14.2\%) contribute more or less evenly to shadow economies. However, according to the estimates constructed using the DGE model, the growth of GDP per-capita has by far the largest effect (24.7\%) followed by indirect taxes (18.5\%), unemployment (18.3\%), tax morale (17.1\%), personal income tax (11.2\%), self-employment (5.8\%), and business freedom (4.3\%). Our analysis generally shows that even though the two datasets are similar in levels and both illustrate a declining trend of shadow economy size over the period of the analysis, they indicate certain differences with respect to the effects of causal variables on shadow economies.
\end{abstract}

Keywords: shadow economy, MIMIC approach, dynamic general equilibrium models.

JEL-Classification: K42, H26, D78, E26

\section{OECD Üyesi Ülkelerde Kayıtdışı Ekonomi: Dinamik Genel Denge ve MIMIC Yöntemleri}

\section{Özet}

Bu makalede OECD üyesi 38 ülke için iki farklı yöntemle kayıtdışı ekonomi tahmin seviyeleri ve kayıtdışı ekonominin belirleyicileri karşılaştırılmaktadır. Yöntemlerden biri MIMIC yöntemine diğeri ise Elgin ve Öztunalı (2012) çalışmasında geliştirilen iki sektörlü dinamik genel denge modeline dayanmaktadır. Sonuçlarımız, MIMIC yönteminin kayıtdış1 ekonominin temel belirleyicileri olarak, gelir vergisi (\%13.8) dolaylı vergiler (\%14.1), vergi ahlakı (\%14.5), işsizlik (\%14.7), serbest-meslek oranı (\%14.5),

\footnotetext{
* Friedrich Schneider is a Professor in the Department of Economics at Johannes Kepler University of Linz, Altenbergerstr. 69, A-4040 Linz, Austria. E-mail: friedrich.schneider@jku.at, http://www.econ.jku.at/schneider

** Ceyhun Elgin is an Associate Professor in the Department of Economics at Boğaziçi University, 34342, Bebek, İstanbul, Turkey. E-mail: ceyhun.elgin@boun.edu.tr, http://www.econ.boun.edu.tr/elgin
} 
GSYİH büyümesi (\%14.3) ve işletme özgürlüğü endeksi (\%14.2)’1 işaret etmektedir. Ancak, dinamik genel denge yöntemine dayanan tahminler için ise temel belirleyiciler olarak GSYİH büyümesi (\%24.7\%) dolaylı vergiler (\%18.5), işsizlik (\%18.3), vergi ahlakı (\%17.1),gelir vergisi (\%11.2), serbest meslek oranı (\%5.8), ve işletme özgürlüğü endeksini (\%4.3) göstermektedir. Sonuçlarımız genel olarak iki yöntemin benzer büyüklük seviyeleri tahminlemesine karşın, kayıtdışı ekonominin belirleyicilerinin etkileri yönünden farklılaştığını ortaya koymaktadır.

Anahtar Kelimeler: kayıtdışı ekonomi, MIMIC yöntemi, dinamik genel denge modelleri.

JEL Sinıflamasi: K42, H26, D78, E26

S hadow economy, sometimes also titled black, hidden, informal, parallel, second or underground economy (or sector) is generally defined as a set of economic activities that takes place outside the framework of bureaucratic public and private sector establishments. Ihrig and Moe (2004) define it as a sector, which produces legal goods but does not comply with government regulations. (Also see Thomas (1999) and Schneider and Enste (2000) for similar definitions.) As the shadow economy severely undermines a government's fiscal stance, reducing the shadow economy size and fighting tax evasion are among the roadmaps of any government. This is one of the main reasons of why there is an increasing attention to an economic analysis of the shadow economy in recent years. However, one particular setback, which, despite the development of various methods, still persists in the literature, is the lack of consensus on the measurement of the shadow economy, thus inhibiting construction of significantly large datasets that would make informality subject to robust (applied) policy analysis.

However there are various methodologies suggested for the measurement of the shadow economy size, this issue mostly arises due to the fact that the size of the shadow economy, by definition, is hard to measure. Most of the suggested methodologies. with two exceptions, are usually used for a particular country or even a region and could not be generalized to cross-country panel frameworks. One such exception is the dataset presented by Buehn and Schneider (2012a), which reports the shadow economy size (as $\%$ of GDP) for 162 countries in an annual basis for the 9 years between 1999 and 2007. In this study, the authors rely on the MIMIC (Multiple Indicators and Multiple Causes) approach to estimate the size of the shadow economy; this approach has been extended in more recent papers. (See Buehn and Schneider, 2012b, 2013 and Schneider, 2013) On the other hand, another recently developed approach by Elgin and Oztunali (2012) is based on the calibration-simulation of a two-sector (formal and shadow) dynamic general equilibrium (DGE) model. ${ }^{[1]}$ In their paper the authors use the model to construct

[1] There is a substantial literature that documents that a large part of informal output is produced by formal firms employing registered workers and both approaches allow for this type of informality in their estimations. 
an annual unbalanced panel dataset of shadow economy size [as \% of GDP ${ }^{[2]}$ ] for 161 countries in an annual basis for the 61 years between 1950 and 2010.

In this paper and for the first time we aim to make two specific contributions: First, we critically compare the two (relatively large) panel datasets on shadow economy size. Second and more importantly we analyze and compare the relative impacts of the causal variables on the size and development of the shadow economy in these two datasets. Our analysis shows that even though the two datasets are similar in levels and both illustrate a declining trend of shadow economy size over the period of analysis, they indicate certain differences with respect to the effects of causal variables on shadow economies. Particularly, the estimates obtained using the MIMIC model imply that the all the seven examined driving forces of shadow economies have similar effects in magnitude. Between 1999 and 2010 unemployment and self-employment on average have the largest impacts (both 14.6\%), followed by tax morale (14.5\%), growth of GDP per-capita $(14.3 \%)$, business freedom $(14.2 \%)$, indirect taxes $(14.1 \%)$ and personal income tax (13.8\%). However, according to the estimates constructed using the DGE model growth of GDP, per-capita has by far the largest effect $(24.8 \%)$ followed by indirect taxes (18.5\%), unemployment (18.2\%), tax morale (17.1\%), personal income tax (11.2\%), self-employment (5.8\%), and business freedom index (4.3\%). These striking differences in the estimated effects of the causal variables indicate that the policy recommendations of both approaches are also different.

The reminder of the paper is organized as follows: Section 2 reviews the two main approaches (MIMIC and the DGE) to estimate shadow economy size as well as to exemplify clearly how we construct the estimates for a selection of five selected economies. Next, in section 3 we present shadow economy size estimations using these two approaches and make a comparison between them. Then, in section 4 we analyze the relative impacts of the causal variables on the size and development of the shadow economy. Finally, in section 5 we provide concluding remarks and a discussion of our results.

\section{Measuring Shadow Economies}

There are numerous approaches to measure the size and development of a shadow economy and they will not be evaluated here ${ }^{[3]}$ Among these we will concentrate on the MIMIC and DGE approaches because these are the only approaches that have been used to produce large cross-country panel datasets. ${ }^{[4]}$

\section{MIMIC Approach}

The MIMIC approach generally builds upon the works of Weck (1983) and of Frey and Weck (1983) and is essentially based on the use of a specific structural equation

\footnotetext{
${ }^{[2]}$ Here it is implicitly assumed that the official GDP calculations do not incorporate informal value added.

[3] See Schneider and Enste (2000), Feld and Schneider (2010), Schneider (2011), Elgin and Oztunali (2012) and Schneider and Williams (2013) for evaluations of different approaches to measure shadow economy size.

[4] Our choices of these two approaches are entirely motivated by the availability of data that can be made subject to empirical analysis for a comparison.
} 
model. It is based on the statistical theory of unobserved variables, which considers multiple causes and indicators of the phenomenon to be measured; i.e. it explicitly considers multiple causes leading to the existence and growth of the shadow economy, as well as the multiple effects of the shadow economy over time. ${ }^{[5]}$ In particular, we use a Multiple Indicators Multiple Causes (MIMIC) model - a particular type of a structural equations model (SEM) - to analyze and estimate the shadow economies of 162 countries around the world. ${ }^{[6]}$

The main idea behind SEM is to examine the relationships among unobserved variables with respect to the relationships among a set of observed variables by using the covariance information of the latter. In particular, SEM compares a sample covariance matrix, i.e. the covariance matrix of the observed variables, with the parametric structure imposed on it by a hypothesized model. ${ }^{[7]}$ The relationships among the observed variables are described in terms of their covariances and it is assumed that they are generated by (a usually smaller number of) unobserved variables. In MIMIC models, the shadow economy is the unobserved variable and is analyzed with respect to its relationship to the observed variables using the covariance matrix of the latter. For this purpose, the unobserved variable is first linked to the observed indicator variables in a factor analytical model, also called a measurement model. Second, the relationships between the unobserved variable and the observed explanatory (causal) variables are specified through a structural model. Thus, a MIMIC model is the simultaneous specification of a factor model and a structural model. In this sense, the MIMIC model tests the consistency of a "structural" theory through data and is thus a rather confirmatory than exploratory technique. In fact, in a confirmatory factor analysis a model is constructed in advance; whether an unobserved (latent) variable or factor influences an observed variable is specified by the researcher, and parameter constraints are often imposed. Thus, an economic theory is tested by examining the consistency of actual data with the hypothesized relationships between observed (measured) variables and the unobserved variable. ${ }^{[8]}$ Such a confirmatory factor analysis has two goals: (i) estimating the parameters

[5] This part closely follows Schneider, Buehn and Montenegro (2010: 9-13).

[6] The latest papers dealing extensively with the MIMIC approach, its development and its weaknesses are from Giles (1999a, 1999b, 1999c), Giles et al. (2002), Dell'Anno (2003), and the excellent study by Giles and Tedds (2002), as well as Bajada and Schneider (2005), Breusch (2005a, 2005b), Schneider (2005, 2007), Pickhardt and Sardà Pons (2006), Chatterjee et al. (2006), Buehn et al. (2009). For a detailed discussion of the strengths and weaknesses see Dell'Anno and Schneider (2009).

[7] Estimation of a SEM with latent variables can be done by means of a computer program for the analysis of covariance structures, such as LISREL (Linear Structural Relations). A useful overview of the LISREL software package in an economics journal is Cziraky (2004). General overviews about the SEM approach are given in e.g. Hayduk (1987), Bollen (1989), Hoyle (1995), Maruyama (1997), Byrne (1998), Muthen (2002), Cziraky (2005).

${ }^{[8]}$ On the contrary, in an exploratory factor analysis a model is not specified in advance; i.e., beyond the specification of the number of latent variables (factors) and observed variables the researcher does not specify any structure of the model. This means assuming that all factors are correlated, all observed variables are directly influenced by all factors, and measurement errors are all uncorrelated with each other. In practice however, the distinction between a confirmatory and an exploratory factor analysis is less strong. Facing poorly fitting models, researchers using SEM techniques 
(coefficients, variances, etc.), and (ii) assessing the fit of the model. Applying this to the shadow economy research, these two goals mean: (a) measuring the relationships of a set of observed causes and indicators to the shadow economy (latent variable), and (b) testing if the researcher's theory or the derived hypotheses, as a whole, fit the data used.

Formally, the MIMIC model consists of two parts: the structural equation model and the measurement model. The structural equation model is given by:

$$
\eta=\gamma^{\prime} \mathbf{x}+\varsigma
$$

where $\mathbf{x}^{\prime}=\left(x_{1}, x_{2}, \ldots, x_{q}\right)$ is a $(1 \times q)$ vector and each $x_{i}, i=1, \ldots, q$ is a potential cause of the latent variable $\eta$ and $\gamma^{\prime}=\left(\gamma_{1}, \gamma_{2}, \ldots, \gamma_{q}\right)$ is a $(1 \times q)$ vector of coefficients describing the relationships between the latent variable and its causes. Thus, the latent variable $\eta$ is determined by a set of exogenous causes. Since these causes only partially explain the latent variable $\eta$, the error term $\checkmark$ represents the unexplained component. The variance of $\zeta$ is denoted by $\psi$. $\boldsymbol{\Phi}$ is the $(q \times q)$ covariance matrix of the causes $\mathbf{x}$. The measurement model represents the link between the latent variable and its indicators, i.e., the latent variable determines its indicators. The measurement model is specified by:

$$
\mathbf{y}=\lambda \eta+\varepsilon
$$

where $\mathbf{y}^{\prime}=\left(y_{1}, y_{2}, \ldots, y_{p}\right)$ is a $(1 \times p)$ vector of several indicator variables. $\lambda$ is the vector of regression coefficients, and $\boldsymbol{\varepsilon}^{\prime}$ is a $(1 \times p)$ vector of white noise disturbances. Their $(p \times p)$ covariance matrix is given by $\boldsymbol{\Theta}_{\varepsilon}$. Figure 1 shows the structure of the MIMIC model using a path diagram.

Figure 1

\section{General Structure of a MIMIC Model}

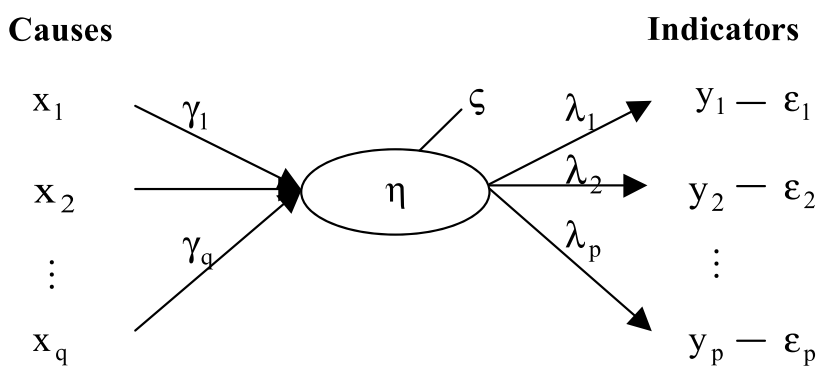

or a confirmatory factor analysis often modify their models in an exploratory way in order to improve the fit. Thus, most applications fall between the two extreme cases of confirmatory (non-specified model structure) and exploratory (ex-ante specified model) factor analysis. 
Using equation (1) in equation (2) yields a reduced form multivariate regression model where the endogenous variables $y_{j}, j=1, \ldots, p$ are the latent variable $\eta$ 's indicators and the exogenous variables $x_{i}, i=1, \ldots, q$ its causes. This model is given by:

$$
\mathbf{y}=\Pi \mathbf{\Pi}+\mathbf{z}
$$

where $\boldsymbol{\Pi}=\boldsymbol{\lambda} \boldsymbol{\gamma}^{\prime}$ is a matrix with rank equal to 1 and $\boldsymbol{z}=\lambda \varsigma+\boldsymbol{\varepsilon}$. The error term $\mathbf{z}$ in equation (3) is a $(p \times 1)$ vector of linear combinations of the white noise error terms $\zeta$ and $\boldsymbol{\varepsilon}$ from the structural equation and the measurement model, i.e. $\mathbf{z} \sim(\mathbf{0}, \boldsymbol{\Omega})$. The covariance matrix $\boldsymbol{\Omega}$ is given by $\operatorname{Cov}(\mathbf{z})=\mathbf{E}\left[(\boldsymbol{\lambda} \varsigma+\boldsymbol{\varepsilon})(\boldsymbol{\lambda} \varsigma+\boldsymbol{\varepsilon})^{\prime}\right]=\lambda \boldsymbol{\lambda}^{\prime} \psi+\boldsymbol{\Theta}_{\varepsilon}$ and is similarly constrained like $\boldsymbol{\Pi}$. The identification and estimation of the model therefore requires the normalization of one of the elements of the vector $\lambda$ to an a priori value (Bollen 1989). From equations (1) and (2) we can derive the MIMIC model's covariance matrix $\boldsymbol{\Sigma}(\boldsymbol{\theta})$. This matrix describes the relationship between the observed variables in terms of their covariances. Decomposing the matrix yields the structure between the observed variables and the latent variable. This covariance matrix is given by:

$$
\boldsymbol{\Sigma}(\boldsymbol{\theta})=\left(\begin{array}{cc}
\lambda\left(\boldsymbol{\gamma}^{\prime} \boldsymbol{\Phi} \boldsymbol{\gamma}+\psi\right)+\boldsymbol{\Theta}_{\varepsilon} & \lambda \gamma^{\prime} \boldsymbol{\Phi} \\
\boldsymbol{\Phi} \gamma \lambda^{\prime} & \boldsymbol{\Phi}
\end{array}\right),
$$

where $\boldsymbol{\Sigma}(\boldsymbol{\theta})$ is a function of the parameters $\boldsymbol{\lambda}$ and $\boldsymbol{\gamma}$ and of the covariances contained in $\boldsymbol{\Phi}, \boldsymbol{\Theta}_{\varepsilon}$, and $\psi$. If the hypothesized model is correct and the parameters are known, the population covariance matrix $\boldsymbol{\Sigma}$ would be exactly reproduced by estimation of the model, i.e $\boldsymbol{\Sigma}$ will equal $\boldsymbol{\Sigma}(\theta)$. In practice, one does however not know either the population variances and covariances or the parameters, but uses the sample covariance matrix of the observed variables, i.e. of $\mathbf{y}$ (vector of indicators) and $\mathbf{x}$ (vector of causes), and sample estimates of the unknown parameters for estimation of the model. The goal of the estimation procedure then is to estimate the parameters and covariances that produce an estimate for $\boldsymbol{\Sigma}(\boldsymbol{\theta}), \hat{\boldsymbol{\Sigma}}=\boldsymbol{\Sigma}(\hat{\boldsymbol{\theta}})$ that is as close as possible to the sample covariance matrix of the observed causes and indicators. The function that measures how close a given $\mathbf{\Sigma}^{*}$ is to the sample covariance matrix $\mathbf{S}$ is called fitting function $\mathrm{F}\left(\mathbf{S} ; \mathbf{\Sigma}^{*}\right)$. The most widely used fitting function for SEM is the Maximum Likelihood (ML) function:

$$
\mathrm{F}_{\mathrm{ML}}=\log |\mathbf{\Sigma}(\theta)|+\operatorname{tr}\left[\mathbf{S} \mathbf{\Sigma}^{-\mathbf{1}}(\theta)\right]-\log |\mathbf{S}|-(\mathrm{p}+\mathrm{q})
$$

where $\log ||$ is the $\log$ of the respective matrix's determinant and $(p+q)$ is the number of observable variables. In general, no closed form or explicit solution for the structural parameters that minimize $\mathrm{F}_{\mathrm{ML}}$ exists. Hence, the estimates that minimize the fitting function are derived applying iterative numerical procedures (see appendix 4C in Bollen (1989) for details). 
In summary, the first step in the MIMIC model estimation is to confirm the hypothesized relationships between the shadow economy (the latent variable) and its causes and indicators. Once the relationships are identified and the parameters estimated, the MIMIC model results are used to calculate the MIMIC index. However, this analysis provides only relative estimates, not absolute, of the size of the shadow economy. Therefore an additional procedure, benchmarking or calibration procedure, is required in order to calculate absolute values of the size of the shadow economy.

The MIMIC approach is generally praised for its formalization of the shadow economy as the outcome of a multitude of causes like taxes, unemployment and institutional quality indices. However, it has been also criticized for being based on the use of certain ad-hoc econometric specifications thereby making it subject to measurement errors. Moreover, another shortcoming of this approach is that it does not rely on any microfoundations. Breusch $(2005 \mathrm{a}, 2005 \mathrm{~b})$ is one of the heavy $\operatorname{critics}^{[9]}$ of using the MIMIC approach for this purpose and argues that the method is pliable and subjective. ${ }^{[10]}$ Yet another criticism is that the method lacks the economic theory to guide the estimation and relies on a complex estimation strategy.

In this paper, we use the MIMIC estimates of Buehn and Schneider (2013) for 38 countries from 1999 to 2010 in which the authors use personal income tax (as \% of GDP), payroll taxes, indirect taxes (both as \% of total tax revenue), tax morale (an index obtained from World Values Survey measuring the extent to which cheating on taxes is justified or not), unemployment ( $\%$ of total labor force), business freedom (an index measuring efficiency of government regulation of business, obtained from the Heritage Foundation), self-employment ( $\%$ of total employment), rule of law (an index summarizing the quality of contract enforcement, the police, and the courts, as well as the likelihood of crime and violence,), growth of GDP per-capita (in \%) education (secondary school enrollment ratio in gross \%) and corruption index (measuring the extent to which corruption prevails in a country) among causes, and GDP per-capita (in constant 2005 USD), currency in circulation (as a ratio to M1) and labor force participation rate (\% of total working-age population) among indicators of shadow economies.

\section{DGE Approach}

In a recent paper, Elgin and Oztunali (2012) use a two-sector dynamic general equilibrium model and present a new approach to estimate the size of the shadow economy. Their micro-founded and therefore theoretically motivated methodology uses national income statistics and a DGE to back out shadow economy size from the model. Using this model the authors construct an annual unbalanced 161-country panel dataset over

\footnotetext{
[9] See also the "reply" by Dell' Anno and Schneider (2006, 2009).

${ }^{[10]}$ Nevertheless, as argued by Giles and Tedds(2002b), "Whatever methodology one adopts in a situation of this kind, assumptions must be made and data issues must be resolved, and many of these assumptions and issues are open to debate."
} 
the period from 1950 to 2010. This aims to be the largest dataset in the literature, particularly with its time-series dimension. Among many possible advantages regarding its use, the construction of such a dataset would also allow for various policy analyses that require a significantly large time dimension. However, one possible criticism of this approach can be made regarding its reliance on the use of national income statistics, which limits the number of variables that potentially might affect or be affected from shadow economy size.

To illustrate how one can construct a shadow economy series for a particular country using this approach, we can assume the existence of a simple representative-agent environment consisting of a representative (stand-in) household-firm that obtains utility from consumption and leisure. This agent is assumed to maximize the following discounted (at rate $0<\beta<1$ ) utility:

$$
\sum_{t=0}^{\infty} \beta^{t} U\left(C_{t}, L_{t}\right)
$$

subject to the following two constraints:

$$
\begin{gathered}
C_{t}+K_{t+1}-(1-\delta) K_{t}=(1-\tau) \theta_{F, t} K_{t}^{\alpha} N_{F, t}^{\alpha}+(1-p \tau) \theta_{S, t} N_{S, t}^{\gamma} \\
N_{F, t}+N_{S, t}+L_{t}=T
\end{gathered}
$$

In this setup, the representative household-firm lives infinitely, has initially $\mathrm{K}_{0}$ units of capital and $\mathrm{T}>0$ units of time endowment in every period. The household has access to two production technologies: It can produce in the formal (official) or informal (shadow) sector. In this specification $C_{t}$ denotes consumption, $L_{t}$ denotes leisure. Formal sector exhibits constant returns to scale production, which equals $\theta_{F, t} K_{t}^{\alpha} N_{F t}^{1-\alpha}$, where $\theta_{F, t}$ is the total factor productivity (TFP) in the formal sector and $\mathrm{N}_{\mathrm{Ft}}$ represents time devoted to working in the formal sector. The formal sector production function uses both capital (which depreciates at a rate equal to $\delta$ ) and labor as inputs. Notice that income of this household-firm from the formal sector is taxed at the rate $\tau$. The informal sector technology, using only labor as input, on the other hand is characterized by $\theta_{S, t} N_{S t}^{\gamma}$, where $\theta_{S, t}$ is the TFP parameter and $N_{S t}$ represents time spent working in the informal sector. When operating in the informal economy, this agent hides his income generated from this sector, as he is only subject to $p$ fraction (where $0 \leq p \leq 1$ ) of the tax rate imposed on the formal sector income. In a sense, the parameter $p$ denotes the level of tax enforcement in the economy. In this setup the first constraint is the budget constraint of this representative agent and the second equation denotes the time constraint. Moreover, it is also assumed that government's policy vector $\{\tau, \mathrm{p}\}$ is exogenous 
and government revenue $G_{t}$ is spent on unproductive activities, which neither generates utility for household nor improves production technologies. ${ }^{[1]}$ Once we define a competitive equilibrium for this environment and solve it at the steady-state we end up with the following equation defining informal labor at the steady state as a function of various parameters of the economy:

$$
N_{S_{t}}=\left\{\frac{\gamma \theta_{S_{t}}}{(1-\tau)(1-\alpha) \theta_{F_{t}}}\left[\frac{(1) / \beta-1+\delta}{\alpha\left(1-\tau_{t}\right) \theta_{F_{t}}}\right]^{\frac{a}{1-\alpha}}\right\}^{\frac{1}{1-\gamma}}
$$

To back out the shadow economy size for a specific country and year, Elgin and Oztunali (2012) first, through calibration or assumption, set the values of several parameters of the economy (such as $\beta, \delta, \gamma$, and $\alpha$ ), next they obtain the total factor series from Penn World Tables 8.1 (PWT 8.1) and then they use the equation-above to back out informal labor $N_{\text {st. }}$ Then it is just a matter of calculation to construct the shadow economy size series (as \% of GDP) for 161 countries from 1950 to 2010. (In model's terms this corresponds to $\frac{\theta_{S, t} N_{S, t}^{\gamma}}{\theta_{F, t} K_{t}^{\alpha} N_{F, t}^{\alpha}}$.) One particular feature of this process is that, through the construction of the series, the authors calibrate one particular parameter of the model to match the shadow economy size in 2007 of the series reported in ${ }^{[12]}$ Buehn and Schneider (2012). The authors then use several series from Penn World Tables 8.1 (namely consumption, working-age population, total employment, GDP per-capita, investment, government spending), to construct the shadow economy dataset. In this paper we use the series constructed by Elgin and Oztunali (2012) for 38 OECD economies from 1999 to 2010.

To further illustrate the construction of the DGE dataset, let us explain in more detail how an estimate is produced for a particular country. Similar to the benchmark case reported in Elgin and Oztunali (2012), we chose and $\gamma$ to be equal to 0.425 and calibrate $\alpha$ and $\delta$ from Penn World Tables. ${ }^{[13]}$ Next, for each country $\beta$ is calibrated using the Euler equation obtained from the following first-order conditions of the maximization problem (assuming logarithmic utility) defined above:

\footnotetext{
${ }^{[11]}$ Notice that this is a very simple environment and Roca et al. (2001) and Busato and Chiarini (2004), Ihrig and Moe (2004) and more recently Elgin and Oztunali (2012) use variations of this setup when modeling informality in a dynamic general equilibrium environment. All these papers use similar production functions when modeling informality. The latter paper also presents several robustness analyzes.

${ }^{[12]}$ This parameter of the model has to be calibrated using an alternative shadow economy estimation. Elgin and Oztunali (2012) report several robustness checks and calibrate this parameter using different estimations of shadow economy size or informal employment and end up with similar results.

${ }^{[13]}$ Notice that Elgin and Oztunali (2012) conduct several robustness checks with respect to the different values of the decreasing returns to scale parameter of the informal sector production function and find that the results are not very sensitive to this specific parameter choice.
} 


$$
\frac{C_{t+1}}{C_{t}}=\beta\left[\left(1-\tau_{t}\right) \alpha \frac{Y_{F_{t+1}}}{K_{t+1}}+1-\delta\right]
$$

Here $Y_{F, t}$ denotes the formal sector production function.

When using this equation to calibrate country-specific values of $\beta$ aggregate consumption values are obtained from national income statistics, the tax rate from the Government Finance Statistics of the IMF and the capital stock are constructed using the perpetual inventory method.

The calibrated values for the discount factor are different for different economies (for example they are 0.957 and 0.83 for Austria and Turkey, respectively.) Once these parameters are calibrated we can then use the following equation obtained from the first-order conditions of the model, assuming it to be at the steady state, namely the equation relating physical capital to labor in the formal sector.

$$
K_{t}=N_{F_{t}}\left[\frac{\left(1-\tau_{t}\right) \theta_{F_{t} \alpha}}{(1) / \beta-1+\delta}\right]^{\frac{1}{1-\alpha}} .
$$

One can obtain a series for the formal sector productivity, i.e. $\theta_{F, t}$ directly from the Penn World Tables. Once this is obtained, the growth rate of shadow economy total factor productivity $\theta_{S, t}$ series is constructed assuming that it grows at a rate equal to the average of the formal sector productivity and physical capital. Together with the calibration of $\theta_{S, t}$ such that the shadow economy size in 2007 is equal to the value reported in Buehn and Schneider (2012) one obtains a full series for $\theta_{S, t}$. Once this series is obtained we use the first equation above, defining shadow labor to back out the shadow labor series; finally with these series, the shadow economy size as \% of GDP can easily be calculated using $\frac{\theta_{S, t} N_{S, t}^{\gamma}}{\theta_{F,} K_{,} N_{F, t}}$

$$
\overline{\theta_{F, t} K_{t}^{\alpha} N_{F, t}^{\alpha}}
$$

As a critic of the DGE approach, we should acknowledge the fact that the calibration / simulation exercise is also prone to other types of measurement errors. For example, one cannot "prove" that the households divide their labor between formal and shadow economies exactly in the way suggested by the DGE model. It is only a theoretical construct and households' behavior can potentially deviate from what the DGE model suggests.

\section{Comparing the Two Methods}

In this subsection we present the estimates obtained for five selected economies, namely Turkey, Austria, France, Germany, and Spain. To this end, Figures 2 to 6 illustrate the behavior of the two series (MIMIC vs. DGE) for these five different OECD economies. 
Figure 2

Shadow Economy Size in Turkey: MIMIC vs. DGE

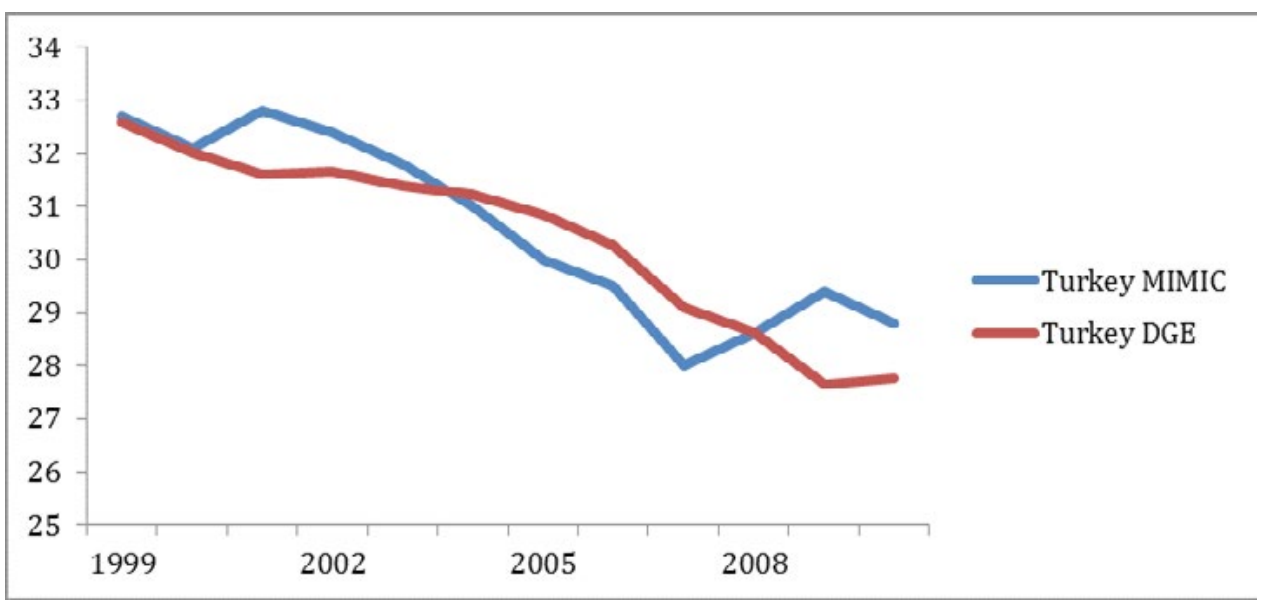

Figure 3

Shadow Economy Size in Austria: MIMIC vs. DGE

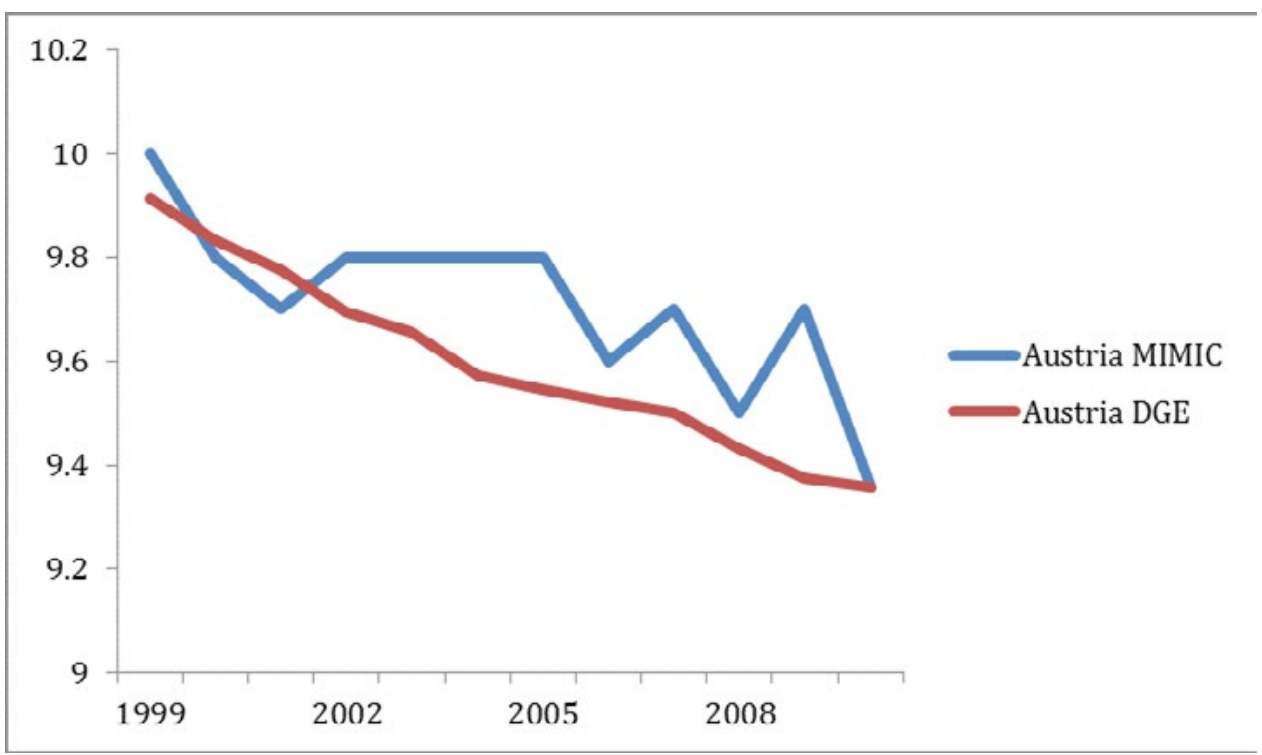


Figure 4

Shadow Economy Size in France: MIMIC vs. DGE

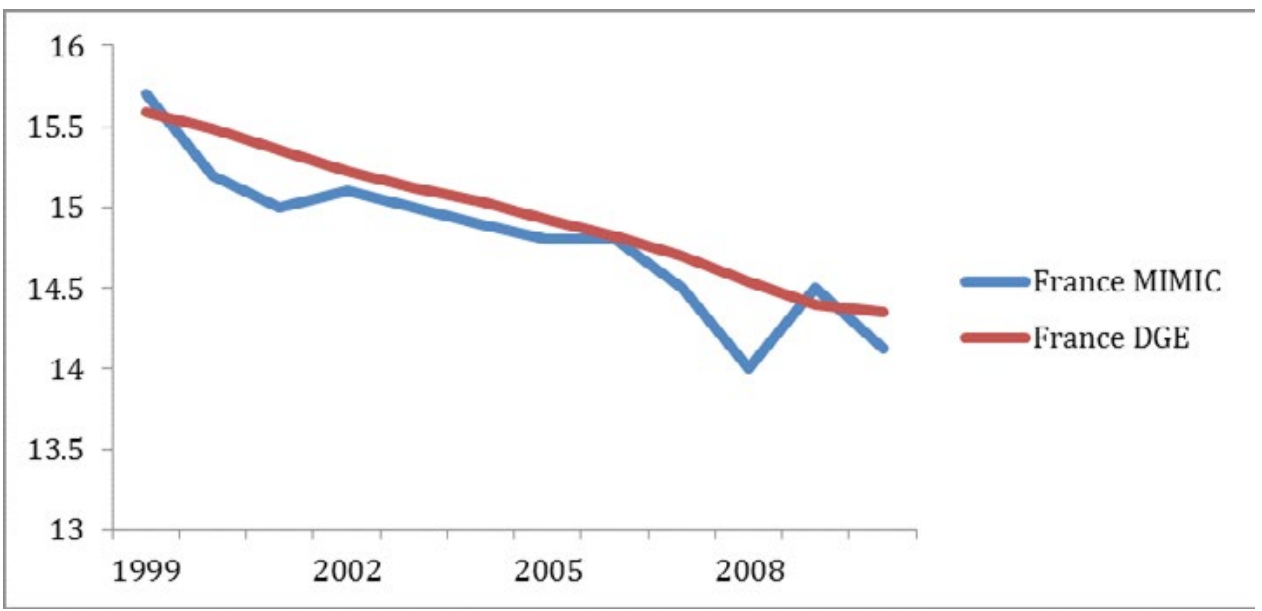

Figure 5

Shadow Economy Size in Germany: MIMIC vs. DGE

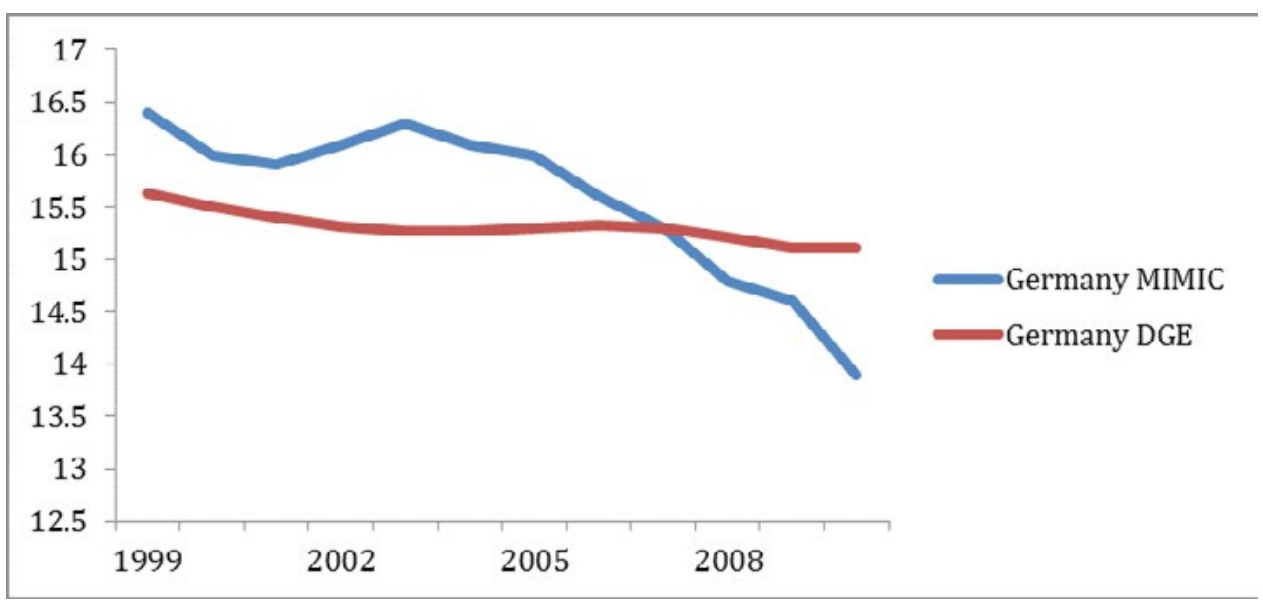


Figure 6

Shadow Economy Size in Spain: MIMIC vs. DGE

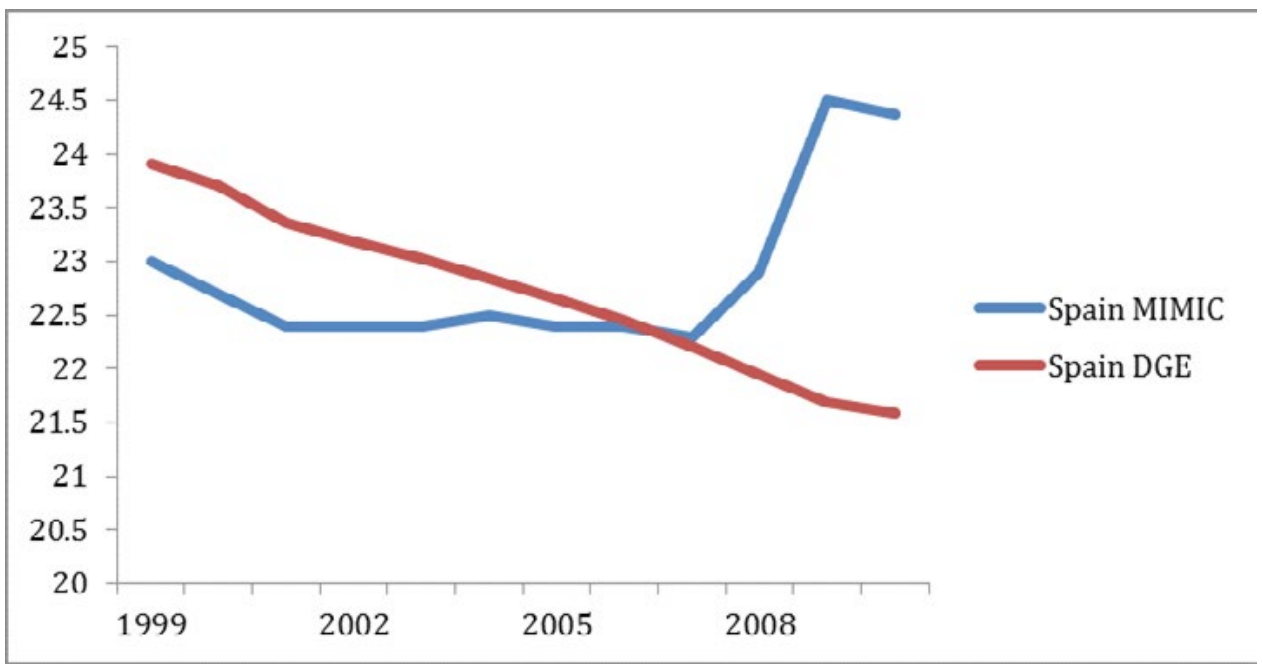

When comparing these estimates based on these five figures, the first observation we make is that the estimates are generally comparable in levels. Surely, in certain years, they go into opposite directions; however considering the short ranges on the y-axes of all the figures, one can observe that the estimates of both approaches are not statistically significant from each other. However, this does not mean that they point out the same direction for all the years and countries. When we compare the correlations of both series, we observe that they exhibit a strong positive correlation with each other for Turkey (0.87). For France, the correlation is even larger, 0.92. However, for Austria, it is reduced to 0.76, for Germany further reduced 0.73 and for Spain it is strikingly negative, being -0.57 .

Yet another difference between the estimates of two methods is that the estimates obtained through the MIMIC approach exhibit a larger variation than the ones by the DGE method. The reason for this difference lies in the way these estimates are constructed. As explained in the previous section, the MIMIC approach relies on a structural equation model with different indicators and causes. Since these indicators and causes might exhibit a strong variation through the period of analysis and they affect the constructed informal sector estimate in a linear way (through the structural equation model), the estimates might well mimic the variation of the causes and indicators. On the other hand, the DGE method exhibits a stronger declining the trend over the period of analysis. This is due the fact that the informal sector production function in the DGE model only employs labor as opposed to the formal sector production function which employs both capital and labor. In the process of capital accumulation, this might create a strong downwards trend for informality. Yet another difference of the DGE approach is that the original estimates of Elgin and Oztunali (2012) are constructed for the period from 1950 to 2010. By doing so, the authors calibrated their parameters taking into account the national income statistics 
for all the years in this period. However, the above-presented figures only illustrate a small fraction (about one sixth) of this dataset, even though they rely on the calibrated parameters for the whole period. This might be another reason behind the differences of the estimates by the two approaches.

Even with a comparison of the two approaches in these five countries, we can make one particular observation: Even though the two methodologies in the two countries produce similar estimates in levels, we suspect that the series' driving forces are strikingly different as the changes in the estimates might be very different in some episodes. This is why we compare and contrast the two series in much deeper detail in the next two sections.

\section{Shadow Economy Estimates}

We have constructed shadow economy series using both the MIMIC and the DGE approaches for 38 OECD economies (See Table 1 for the list of countries) from 1999 to 2010. As we have mentioned above, for the MIMIC methodology, we use the estimates reported in Buehn and Schneider (2013) and the DGE estimates are obtained from Elgin and Oztunali (2012). Table 2 reports descriptive summary statistics of both series for each of the 38 countries from 1999 to 2010 in our dataset. What we observe from Table 2 is that the two series, which are obtained using two different methodologies, are strikingly similar to each other with respect to the average values of the mean, standard deviation, minimum and maximum values of the shadow economy size estimates. ${ }^{[14]}$ Even though there are some differences on a country-by-country basis between the two series, the differences of these four statistics are not statistically significant when we compare them using a standard mean comparison t-test.

Next, in Figure 7 we illustrate the evolution of the (unweighted) average shadow economy size across the period from 1999 to 2010 with both shadow economy series. As evident from the figure, there is a secularly declining trend of shadow economy size over the 12 years; however the pace of the decline is larger in the DGE series compared to the MIMIC estimations. Moreover, in the MIMIC series there is an increase of the average shadow economy size after the crisis in 2008; which we don't observe in the DGE series. Even though the DGE the rate of the reduction of the shadow economy size in the DGE series is significantly decreased in 2008, we don't observe an increase in the estimate for this year.

Table 1

OECD Countries Included in the Sample<. Estimation Period: 1999-2010

Australia, Austria, Belgium, Bulgaria, Canada, Chile, Cyprus, Czech Republic, Denmark, Estonia,

Finland, France, Germany, Greece, Hungary, Iceland, Ireland, Italy, Korea, Latvia, Lithuania,

Luxembourg, Malta, Mexico, Netherlands. New Zealand, Norway, Poland, Portugal, Romania, Slovak

Republic, Slovenia, Spain, Sweden, Switzerland, Turkey, United Kingdom, United States

${ }^{[14]}$ One problem of this comparison is that Elgin and Oztunali (2012) calibrate their model to match the 2007 values reported in Buehn and Schneider (2012). This process might create a bias towards similar values of both series. However, the variations of both series are completely different. Also please see the footnote 8 on this. 
Table 2

Shadow Economy Size (Descriptive Statistics): MIMIC and DGE Series from 1999 to 2010

\begin{tabular}{|c|c|c|c|c|c|c|c|c|}
\hline \multirow[b]{2}{*}{ Country } & \multicolumn{4}{|c|}{ MIMIC } & \multicolumn{4}{|c|}{ DGE } \\
\hline & Mean & $\begin{array}{l}\text { Std. } \\
\text { Dev. }\end{array}$ & Min. & Max. & Mean & $\begin{array}{l}\text { Std. } \\
\text { Dev. }\end{array}$ & Min. & Max. \\
\hline Australia & 13.83 & 0.38 & 13.2 & 14.4 & 13.93 & 0.63 & 12.93 & 14.82 \\
\hline Austria & 9.82 & 0.28 & 9.5 & 10.6 & 9.6 & 0.18 & 9.36 & 9.91 \\
\hline Belgium & 21.53 & 0.77 & 20.3 & 22.7 & 21.57 & 0.51 & 20.77 & 22.41 \\
\hline Bulgaria & 34.64 & 1.87 & 31.9 & 37.3 & 33.41 & 1.52 & 30.52 & 34.79 \\
\hline Canada & 15.59 & 0.38 & 14.9 & 16.3 & 15.75 & 0.65 & 14.74 & 16.67 \\
\hline Chile & 19.40 & 0.59 & 18.4 & 20.5 & 19.11 & 0.9 & 17.74 & 20.46 \\
\hline Cyprus & 27.71 & 0.96 & 25.4 & 29.2 & 26.58 & 0.45 & 25.69 & 26.98 \\
\hline Czech Republic & 17.58 & 1.53 & 15.2 & 19.3 & 17.3 & 0.54 & 16.44 & 18.02 \\
\hline Denmark & 17.25 & 0.98 & 15.3 & 18.4 & 17.35 & 0.64 & 16.47 & 18.39 \\
\hline Estonia & 23.66 & 1.44 & 20.8 & 25.6 & 27.7 & 1.99 & 25.98 & 30.12 \\
\hline Finland & 17.38 & 0.65 & 16.4 & 18.4 & 17.31 & 0.53 & 16.52 & 18.07 \\
\hline France & 14.84 & 0.43 & 14 & 15.7 & 14.96 & 0.41 & 14.35 & 15.59 \\
\hline Germany & 15.68 & 0.6 & 14.6 & 16.4 & 15.31 & 0.15 & 15.11 & 15.63 \\
\hline Greece & 27.00 & 1.2 & 25.1 & 28.7 & 27.19 & 1.03 & 25.74 & 28.82 \\
\hline Hungary & 24.08 & 0.78 & 23.1 & 25.4 & 24.24 & 0.71 & 23.29 & 25.4 \\
\hline Iceland & 15.21 & 0.75 & 13.8 & 16 & 15.58 & 0.81 & 14.3 & 16.63 \\
\hline Ireland & 16.04 & 0.52 & 15.5 & 17.5 & 15.96 & 0.83 & 14.86 & 17.37 \\
\hline Italy & 26.93 & 0.33 & 26.5 & 27.8 & 27.25 & 0.62 & 26.42 & 28.22 \\
\hline Republic of Korea & 26.34 & 1.12 & 24.5 & 28.3 & 26.48 & 1.25 & 24.71 & 28.41 \\
\hline Latvia & 22.12 & 1.22 & 20 & 23.9 & 24.77 & 2.01 & 20.85 & 27.12 \\
\hline Lithuania & 25.43 & 1.24 & 23.6 & 27.2 & 28.42 & 1.76 & 25.09 & 31.04 \\
\hline Luxembourg & 9.63 & 0.27 & 9.1 & 10 & 9.62 & 0.35 & 9.12 & 10.16 \\
\hline Malta & 27.26 & 0.38 & 26.7 & 28.1 & 26.42 & 0.15 & 26.2 & 26.73 \\
\hline Mexico & 30.00 & 0.54 & 28.8 & 30.8 & 29.61 & 0.64 & 28.81 & 30.87 \\
\hline Netherlands & 13.16 & 0.22 & 12.7 & 13.6 & 13.15 & 0.29 & 12.7 & 13.66 \\
\hline New Zealand & 12.25 & 0.37 & 11.8 & 13 & 12.34 & 0.46 & 11.69 & 13 \\
\hline Norway & 18.59 & 0.48 & 17.7 & 19.2 & 18.28 & 0.54 & 17.33 & 19.03 \\
\hline Poland & 26.44 & 1.43 & 23.8 & 27.7 & 26.7 & 1.19 & 24.83 & 28.59 \\
\hline Portugal & 22.68 & 0.46 & 21.9 & 23.3 & 23.53 & 0.79 & 22.63 & 25.07 \\
\hline Romania & 32.19 & 1.51 & 30 & 34.4 & 30.27 & 0.75 & 28.81 & 31.02 \\
\hline Slovak Republic & 17.55 & 1.23 & 15.8 & 18.9 & 17.06 & 0.42 & 16.38 & 17.51 \\
\hline Slovenia & 25.71 & 1.26 & 23.5 & 27.3 & 25.42 & 1.31 & 23.4 & 27.45 \\
\hline Spain & 22.78 & 0.65 & 22.3 & 24.5 & 22.72 & 0.76 & 21.59 & 23.92 \\
\hline Sweden & 18.55 & 0.59 & 17.7 & 19.6 & 18.08 & 0.42 & 17.41 & 18.67 \\
\hline Switzerland & 8.32 & 0.48 & 7.2 & 8.8 & 8.13 & 0.06 & 8.05 & 0.23 \\
\hline Turkey & 30.61 & 1.72 & 28 & 32.8 & 30.40 & 1.7 & 27.66 & 32.58 \\
\hline United Kingdom & 12.48 & 0.27 & 12 & 12.9 & 12.48 & 0.44 & 11.9 & 13.21 \\
\hline United States & 8.74 & 0.25 & 8.4 & 9.3 & 8.66 & 0.35 & 8.24 & 9.27 \\
\hline Average & 20.24 & 0.79 & 18.93 & 21.42 & 20.33 & 0.76 & 19.17 & 21.21 \\
\hline
\end{tabular}

Source: Authors' calculations 
As looking at unweighted series might be a misleading way of calculating the shadow economy size in a group of countries, in Figure 8 we plot the evolution of the GDPweighted average shadow economy size in our 38-country group. As ceteris paribus, richer countries tend to have a smaller shadow economy (tough the relationship is not totally linear) once we weight the shadow economy size with GDP, the group average is significantly reduced.

Figure 7

Average Shadow Economy Size (Unweighted) of 38 OECD-Countries

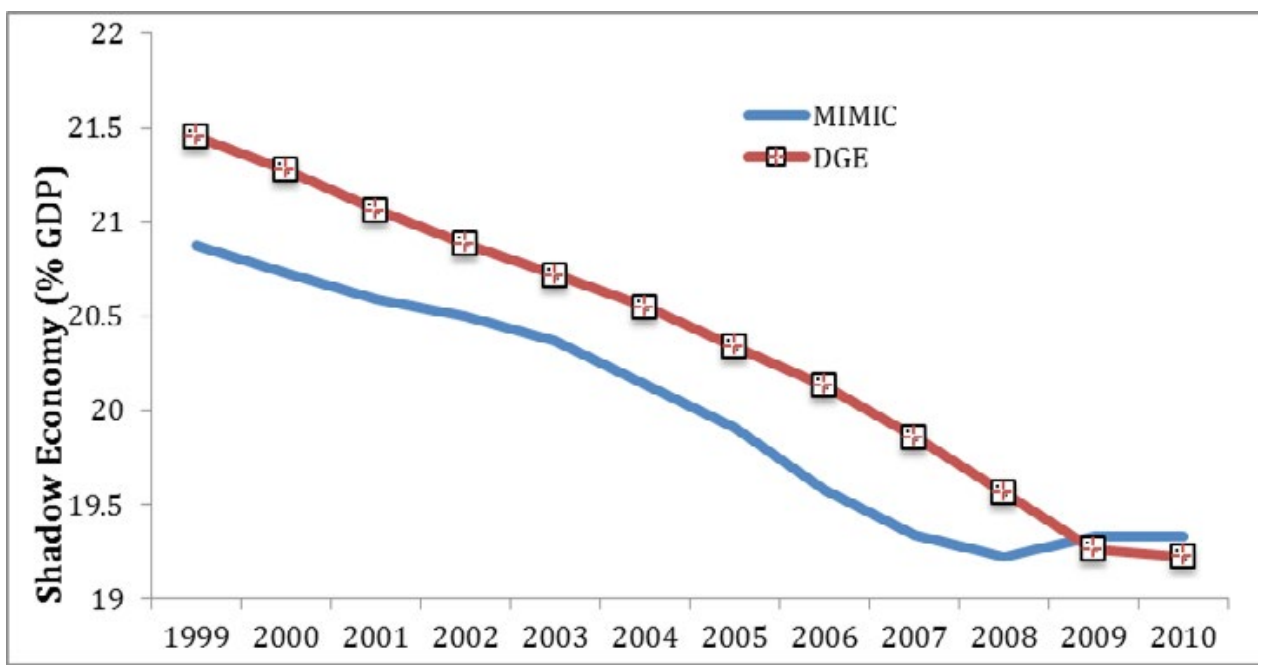

Figure 8

Average Shadow Economy Size (GDP - weighted) of 38 OECD-Countries

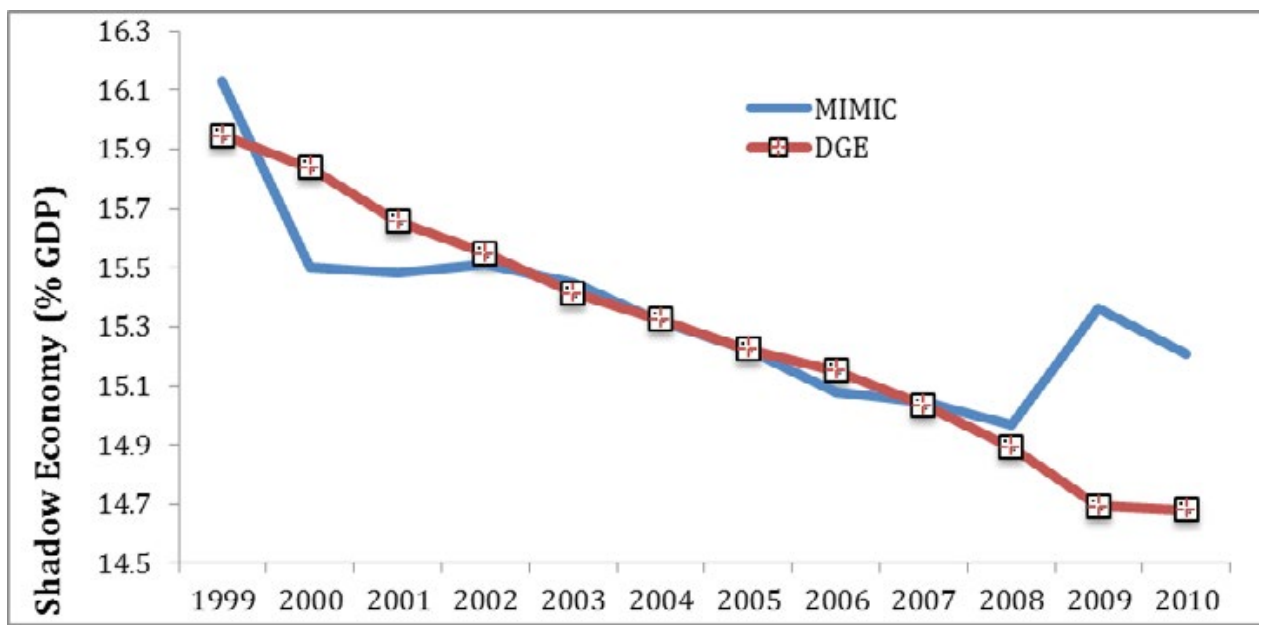


Table 3

Average Relative Impact (in \%) of the Causal Variables on the Shadow Economy (MIMIC) of 38 OECD Countries over 1999 to 2010

\begin{tabular}{|c|c|c|c|c|c|c|c|c|}
\hline Country & $\begin{array}{l}\text { Average size } \\
\text { of the shad- } \\
\text { ow economy }\end{array}$ & $\begin{array}{c}\text { Personal } \\
\text { income } \\
\text { tax }\end{array}$ & $\begin{array}{c}\text { Indirect } \\
\text { taxes }\end{array}$ & $\begin{array}{l}\text { Tax } \\
\text { mo- } \\
\text { rale }\end{array}$ & $\begin{array}{l}\text { Unem- } \\
\text { ployment }\end{array}$ & $\begin{array}{c}\text { Self- } \\
\text { employ- } \\
\text { ment }\end{array}$ & $\begin{array}{c}\text { GDP } \\
\text { growth }\end{array}$ & $\begin{array}{c}\text { Busi- } \\
\text { ness } \\
\text { freedom }\end{array}$ \\
\hline Australia & 13.8 & 12.4 & 13.4 & 14.1 & 18.1 & 15.8 & 13.2 & 13.0 \\
\hline Austria & 9.8 & 12.4 & 14.6 & 14.1 & 11.8 & 16.8 & 15.9 & 14.4 \\
\hline Belgium & 21.5 & 12.9 & 12.8 & 14.4 & 16.2 & 16.0 & 14.2 & 13.3 \\
\hline Bulgaria & 34.6 & 14.9 & 13.5 & 14.8 & 14.8 & 14.2 & 13.7 & 14.2 \\
\hline Canada & 15.6 & 12.7 & 14.9 & 14.9 & 18.4 & 11.7 & 13.8 & 13.6 \\
\hline Chile & 19.4 & 16.1 & 14.1 & 14.1 & 14.2 & 12.9 & 14.4 & 14.3 \\
\hline Cyprus & 27.2 & 13.8 & 14.5 & 14.5 & 14.3 & 14.5 & 13.8 & 14.6 \\
\hline Czech Rep. & 17.6 & 15.1 & 16.0 & 14.0 & 11.5 & 13.1 & 14.3 & 15.9 \\
\hline Denmark & 17.3 & 10.8 & 13.1 & 14.7 & 18.2 & 15.6 & 14.4 & 13.2 \\
\hline Estonia & 23.7 & 16.4 & 14.4 & 14.5 & 12.4 & 13.1 & 14.0 & 15.2 \\
\hline Finland & 17.4 & 15.4 & 13.0 & 14.8 & 12.9 & 16.9 & 13.7 & 13.3 \\
\hline France & 14.8 & 9.1 & 14.4 & 14.8 & 15.1 & 17.3 & 15.1 & 14.3 \\
\hline Germany & 15.7 & 16.6 & 13.2 & 15.0 & 13.0 & 12.8 & 15.2 & 14.2 \\
\hline Greece & 27.0 & 10.3 & 16.2 & 14.5 & 10.4 & 18.7 & 14.3 & 15.5 \\
\hline Hungary & 24.1 & 14.0 & 14.1 & 15.0 & 15.0 & 14.2 & 13.5 & 14.2 \\
\hline Iceland & 15.2 & 12.4 & 14.3 & 14.7 & 15.1 & 14.4 & 14.8 & 14.3 \\
\hline Ireland & 16.0 & 13.7 & 13.9 & 14.3 & 18.0 & 12.5 & 13.7 & 14.0 \\
\hline Italy & 26.9 & 13.0 & 13.9 & 14.0 & 14.5 & 14.0 & 16.6 & 13.9 \\
\hline Korea & 26.3 & 13.3 & 14.4 & 14.9 & 13.3 & 14.6 & 15.3 & 14.2 \\
\hline Latvia & 22.2 & 14.6 & 14.3 & 13.9 & 15.1 & 14.6 & 13.3 & 14.2 \\
\hline Lithuania & 25.4 & 13.1 & 14.5 & 14.1 & 15.1 & 14.5 & 14.2 & 14.5 \\
\hline Luxembourg & 9.6 & 14.7 & 14.3 & 14.2 & 13.0 & 14.9 & 14.5 & 14.3 \\
\hline Malta & 27.3 & 14.3 & 14.3 & 15.1 & 14.3 & 14.3 & 13.4 & 14.3 \\
\hline Mexico & 30.0 & 14.3 & 13.7 & 14.5 & 14.4 & 14.2 & 14.9 & 13.9 \\
\hline Netherlands & 13.2 & 14.6 & 13.6 & 14.0 & 16.1 & 13.7 & 14.2 & 13.8 \\
\hline New Zealand & 12.2 & 14.6 & 14.2 & 14.2 & 15.2 & 14.3 & 13.2 & 14.2 \\
\hline Norway & 18.6 & 14.1 & 13.8 & 14.2 & 14.1 & 14.5 & 15.4 & 13.9 \\
\hline Poland & 26.4 & 14.1 & 14.4 & 14.4 & 14.2 & 14.5 & 14.1 & 14.4 \\
\hline Portugal & 22.7 & 12.5 & 14.1 & 14.9 & 14.2 & 14.4 & 15.9 & 14.1 \\
\hline Romania & 32.2 & 15.5 & 14.2 & 13.9 & 14.2 & 14.1 & 14.0 & 14.2 \\
\hline Slovak Rep. & 17.5 & 15.0 & 14.7 & 14.7 & 14.4 & 14.4 & 12.0 & 14.8 \\
\hline Slovenia & 25.2 & 14.4 & 14.3 & 14.4 & 14.8 & 14.4 & 13.2 & 14.4 \\
\hline Spain & 22.8 & 11.2 & 13.6 & 14.6 & 17.5 & 16.4 & 13.8 & 12.9 \\
\hline Sweden & 18.6 & 14.9 & 14.3 & 14.6 & 13.3 & 14.2 & 14.2 & 14.5 \\
\hline Switzerland & 8.3 & 13.8 & 13.0 & 15.7 & 13.4 & 14.4 & 14.8 & 14.8 \\
\hline Turkey & 30.6 & 13.9 & 14.1 & 14.5 & 13.7 & 14.5 & 15.1 & 14.3 \\
\hline $\begin{array}{l}\text { United } \\
\text { Kingdom }\end{array}$ & 12.5 & 13.6 & 14.0 & 14.3 & 18.1 & 12.4 & 13.7 & 14.0 \\
\hline United States & 8.7 & 13.9 & 14.1 & 13.7 & 14.9 & 14.4 & 15.0 & 14.1 \\
\hline Average & 20.2 & 13.8 & 14.1 & 14.5 & 14.7 & 14.5 & 14.3 & 14.2 \\
\hline
\end{tabular}

Source: Schneider and Buehn (2013) 
Table 4

Average Relative Impact (in \%) of the Causal Variables on the Shadow Economy (DGE) of 38 OECD Countries over 1999 to 2010

\begin{tabular}{|c|c|c|c|c|c|c|c|c|}
\hline Country & $\begin{array}{l}\text { Average } \\
\text { size of the } \\
\text { shadow } \\
\text { economy }\end{array}$ & $\begin{array}{c}\text { Personal } \\
\text { income } \\
\text { tax }\end{array}$ & $\begin{array}{c}\text { Indirect } \\
\text { taxes }\end{array}$ & $\begin{array}{c}\text { Tax } \\
\text { morale }\end{array}$ & $\begin{array}{c}\text { Unem- } \\
\text { ployment }\end{array}$ & $\begin{array}{c}\text { Self-em- } \\
\text { ployment }\end{array}$ & $\begin{array}{c}\text { GDP } \\
\text { growth }\end{array}$ & $\begin{array}{l}\text { Business } \\
\text { freedom }\end{array}$ \\
\hline Australia & 13.9 & 10.1 & 17.6 & 16.7 & 22.6 & 6.3 & 22.8 & 3.9 \\
\hline Austria & 9.6 & 10.1 & 19.1 & 16.7 & 14.7 & 6.7 & 28.2 & 4.4 \\
\hline Belgium & 21.6 & 10.5 & 16.8 & 17.0 & 20.2 & 6.4 & 25.0 & 4.0 \\
\hline Bulgaria & 33.4 & 12.2 & 17.7 & 17.5 & 18.5 & 5.7 & 24.2 & 4.3 \\
\hline Canada & 15.8 & 10.4 & 19.5 & 17.6 & 23.0 & 4.7 & 20.7 & 4.1 \\
\hline Chile & 19.1 & 13.2 & 18.5 & 16.7 & 17.7 & 5.2 & 24.5 & 4.3 \\
\hline Cyprus & 26.6 & 11.3 & 19.0 & 17.1 & 17.8 & 5.8 & 24.5 & 4.4 \\
\hline Czech Rep. & 17.3 & 12.3 & 21.0 & 16.6 & 14.4 & 5.2 & 25.7 & 4.8 \\
\hline Denmark & 17.4 & 8.8 & 17.2 & 17.4 & 22.7 & 6.2 & 23.7 & 4.0 \\
\hline Estonia & 31.2 & 13.4 & 18.9 & 17.1 & 15.5 & 5.2 & 25.2 & 4.6 \\
\hline Finland & 17.3 & 12.6 & 17.0 & 17.5 & 16.1 & 6.8 & 26.0 & 4.0 \\
\hline France & 15.0 & 7.4 & 18.9 & 17.5 & 18.8 & 6.9 & 26.1 & 4.3 \\
\hline Germany & 15.3 & 13.6 & 17.3 & 17.7 & 16.2 & 5.1 & 25.7 & 4.3 \\
\hline Greece & 27.2 & 8.4 & 21.2 & 17.1 & 13.0 & 7.5 & 28.0 & 4.7 \\
\hline Hungary & 24.2 & 11.4 & 18.5 & 17.7 & 18.7 & 5.7 & 23.6 & 4.3 \\
\hline Iceland & 15.6 & 10.1 & 18.7 & 17.4 & 18.8 & 5.8 & 24.8 & 4.3 \\
\hline Ireland & 16.0 & 11.2 & 18.2 & 16.9 & 22.5 & 5.0 & 22.0 & 4.2 \\
\hline Italy & 27.2 & 10.6 & 18.2 & 16.6 & 18.1 & 5.6 & 26.7 & 4.2 \\
\hline Korea & 26.5 & 10.9 & 18.9 & 17.6 & 16.6 & 5.8 & 25.9 & 4.3 \\
\hline Latvia & 29.3 & 11.9 & 18.7 & 16.4 & 18.8 & 5.8 & 23.9 & 4.3 \\
\hline Lithuania & 31.4 & 10.7 & 19.0 & 16.7 & 18.8 & 5.8 & 24.6 & 4.4 \\
\hline Luxembourg & 9.6 & 12.0 & 18.7 & 16.8 & 16.2 & 6.0 & 25.9 & 4.3 \\
\hline Malta & 26.4 & 11.7 & 18.7 & 17.9 & 17.8 & 5.7 & 23.8 & 4.3 \\
\hline Mexico & 29.6 & 11.7 & 18.0 & 17.1 & 18.0 & 5.7 & 25.3 & 4.2 \\
\hline Netherlands & 13.2 & 11.9 & 17.8 & 16.6 & 20.1 & 5.5 & 23.9 & 4.2 \\
\hline $\begin{array}{l}\text { New } \\
\text { Zealand }\end{array}$ & 12.3 & 11.9 & 18.6 & 16.8 & 19.0 & 5.7 & 23.7 & 4.3 \\
\hline Norway & 18.3 & 11.5 & 18.1 & 16.8 & 17.6 & 5.8 & 26.0 & 4.2 \\
\hline Poland & 26.7 & 11.5 & 18.9 & 17.0 & 17.7 & 5.8 & 24.7 & 4.4 \\
\hline Portugal & 23.5 & 10.2 & 18.5 & 17.6 & 17.7 & 5.8 & 25.9 & 4.3 \\
\hline Romania & 30.3 & 12.7 & 18.6 & 16.4 & 17.7 & 5.6 & 24.6 & 4.3 \\
\hline Slovak Rep. & 17.1 & 12.3 & 19.3 & 17.4 & 18.0 & 5.8 & 22.9 & 4.5 \\
\hline Slovenia & 25.4 & 11.8 & 18.7 & 17.0 & 18.5 & 5.8 & 23.9 & 4.4 \\
\hline Spain & 22.7 & 9.2 & 17.8 & 17.3 & 21.8 & 6.6 & 23.4 & 3.9 \\
\hline Sweden & 18.1 & 12.2 & 18.7 & 17.3 & 16.6 & 5.7 & 25.1 & 4.4 \\
\hline Switzerland & 8.1 & 11.3 & 17.0 & 18.6 & 16.7 & 5.8 & 26.1 & 4.5 \\
\hline Turkey & 30.4 & 11.4 & 18.5 & 17.1 & 17.1 & 5.8 & 25.8 & 4.3 \\
\hline $\begin{array}{l}\text { United } \\
\text { Kingdom }\end{array}$ & 12.5 & 11.1 & 18.4 & 16.9 & 22.6 & 5.0 & 21.8 & 4.2 \\
\hline $\begin{array}{l}\text { United } \\
\text { States }\end{array}$ & 8.7 & 11.4 & 18.5 & 16.2 & 18.6 & 5.8 & 25.3 & 4.3 \\
\hline Average & 20.6 & 11.2 & 18.5 & 17.1 & 18.3 & 5.8 & 24.7 & 4.3 \\
\hline
\end{tabular}


Figure 8 also reveals another striking difference between the two series considered. Even though similar to the unweighted series, both the DGE and MIMIC series tend to have a declining trend over the period of analysis, the MIMIC series is less smooth and has a significantly higher standard deviation compared to the unweighted counterpart. In particular, the jump of the average shadow economy size after 2008 becomes more obvious in this case. This suggests that the counter cyclicality of the shadow economy (as suggested by Elgin, 2012) throughout the crises years is more evident in the MIMIC series compared to the DGE one.

\section{Driving Forces of Shadow Economies}

Motivated by the differences of the estimates of the two approaches presented in the previous two sections, in this section, similar to Buehn and Schneider (2013), we present the relative impacts of the causal variables on both of the shadow economy series in tables 3 and 4 . Similar to the cited paper, we examine the effects of seven variables on shadow economy size. These are personal income tax, indirect taxes (both as \% of GDP), tax morale, unemployment rate, self-employment ratio, growth of real GDP per-capita and business freedom index. ${ }^{[15]}$ The sources of these series as well as the direction of their effects on shadow economy size are presented in Table 5.

Here we borrow the driving force estimates from the MIMIC approach from Buehn and Schneider (2013). In this paper, to obtain the relative effects of the driving forces of the shadow economies, the authors use the standardized coefficients of the causal variables from the MIMIC model they estimate to construct the shadow economy estimates. (See the cited paper for more details.) In order to obtain comparable estimates for the driving forces under the DGE approach, similar to the standardized coefficients used under the MIMIC approach, we simply obtain the coefficients by regressing the shadow economy series on the causal variables.

The estimates obtained using the MIMIC model imply that personal income tax (13.8\%), indirect taxes (14.1\%), tax morale (14.5\%), unemployment (14.7\%), self-employment (14.5\%), growth of GDP (14.3\%) and business freedom index (14.2\%) contribute more or less evenly to shadow economies. However, according to the estimates constructed using the DGE model growth of GDP, per-capita has by far the largest effect $(24.7 \%)$ followed by indirect taxes $(18.5 \%)$, unemployment (18.3\%), tax morale (17.1\%), personal income tax (11.2\%), self-employment (5.8\%), and business freedom index (4.3\%). These numbers indicate that, even though two methods produce shadow economy estimates highly similar in levels, the implied driving forces are strikingly different. This is also one of the main reasons why the changes in the series are strikingly different even though the levels of the estimates are very similar. In particular, following our discussion on figures 2 and 3 , if we compare the two series for Austria and Turkey, we observe that in the case of

\footnotetext{
${ }^{[15]}$ As an alternative to the business freedom index, we could also use some other institutional quality variable such as corruption control, investment profile or bureaucratic quality. However, due to the fact that these variables are generally very highly correlated with each other, one should not use all in the estimation of the shadow economy series using the MIMIC method. Therefore, as we wanted to use the estimates of Buehn and Schneider (2013) we were bound to use the business freedom index, which was also used by the cited paper.
} 
Austria, the DGE approach relative to the MIMIC approach gives 18.6\% lower weight for personal income tax, about 30.8\% higher weight for indirect taxes, $18.4 \%$ higher weight for tax morale, a $24.5 \%$ higher weight for unemployment, $60.1 \%$ lower weight for selfemployment, $77.3 \%$ higher weight for GDP growth and $69.5 \%$ lower rate for business freedom. In the case of Turkey, the DGE approach gives 18\% lower weight for personal income tax, about 31.2\% higher weight for indirect taxes, $17.9 \%$ higher weight for tax morale, a $24.8 \%$ higher weight for unemployment, $60 \%$ lower weight for self-employment, $70.8 \%$ higher weight for GDP growth and 70\% lower rate for business freedom index. From these numbers, the different weights given in the two methodologies to different variables are obviously behind the differences in the changes of the estimates produced by these methodologies.

Table 5

\section{Causal Variables of Shadow Economies}

\begin{tabular}{|c|c|c|}
\hline Causal Variable & Description and source & Expected sign \\
\hline Business freedom & $\begin{array}{l}\text { Business freedom index measuring the time and efforts of business } \\
\text { activity ranging; } 0=\text { least business freedom, and } 100=\text { maximum } \\
\text { business freedom; Heritage Foundation }\end{array}$ & - \\
\hline GDP growth & GDP per capita growth, annual (\%); WDI & $+/-$ \\
\hline Indirect taxes & Taxes on goods and services (\% of total tax revenue); WDI & + \\
\hline $\begin{array}{l}\text { Personal income } \\
\text { tax }\end{array}$ & $\begin{array}{l}\text { Personal Income Tax (PIT) to GDP, Government Finance Statistics; } \\
\text { International Monetary Fund }\end{array}$ & + \\
\hline Self-employment & Total self-employed workers (proportion of total employment); WDI & + \\
\hline Tax morale & $\begin{array}{l}\text { To assess the level of tax morale we use the following question: } \\
\text { "Please tell me for each of the following statements whether you think } \\
\text { it can always be justified, never be justified, or something in between: } \\
\text {.. Cheating on tax if you have the chance". } \\
\text { The question leads to a 10-scale index of tax morale with the two } \\
\text { extreme points "never justified"' (1) and "always justified" (10). } \\
\text { Using the proportion of respondents who answered the question } \\
\text { with a value of } 6 \text { or higher, higher values of our tax morale variable } \\
\text { indicate a lower level of tax moral; European and World Value } \\
\text { Surveys }\end{array}$ & - \\
\hline Unemployment & Unemployment rate $(\%$ of total labor force; WDI & + \\
\hline $\begin{array}{l}\text { Currency in } \\
\text { circulation }\end{array}$ & $\begin{array}{l}\text { Monetary aggregates M0 over M1; International Monetary Fund, } \\
\text { International Financial Statistics }\end{array}$ & + \\
\hline GDP pc & GDP per capita, PPP (constant 2005 international \$); WDI & - \\
\hline $\begin{array}{l}\text { Labor force } \\
\text { participation }\end{array}$ & Labor force participation rate ( $\%$ of total population); WDI & - \\
\hline
\end{tabular}

At this point, one important question would be whether there are any specific factors that might affect the relative contributions of the causal variables to shadow economy size as well as to the difference in the relative contributions of the two series we use. To this end, we conduct a simple regression analysis by regressing the average relative contribution of each driving force on several variables that might be associated with these. The variables we use as regressors are the capital-output ratio, government 
spending (as \% of GDP), GDP per-capita (in constant 2005 USD) bureaucratic quality index and the democratic accountability index. ${ }^{[16]}$

Table 6

Determinants of the Driving Forces of Shadow Economies

\begin{tabular}{l|c|c|c|c|c|c|c}
\hline Dep. Var.: & Growth & Indirect & Unemp. & Morale & Business & Self-Emp. & PIT \\
\hline Regressor & & & & & & & \\
\hline Capital & $1.14^{*}$ & -0.56 & -1.19 & $0.41^{* * *}$ & -0.08 & 0.82 & -0.60 \\
& $(3.27)$ & $(1.62)$ & $(1.35)$ & $(1.71)$ & $(0.33)$ & $(1.16)$ & $(0.94)$ \\
Gov & -0.05 & -0.05 & 0.10 & -0.01 & -0.03 & 0.08 & -0.03 \\
& $(0.91)$ & $(1.00)$ & $(1.27)$ & $(0.37)$ & $(1.14)$ & $(0.94)$ & $(0.29)$ \\
GDP & 0.02 & -0.006 & -0.01 & $-0.01^{* *}$ & -0.0004 & 0.01 & -0.01 \\
& $(1.44)$ & $(1.07)$ & $(0.51)$ & $(2.19)$ & $(0.08)$ & $(1.13)$ & $(0.46)$ \\
Bur. & -0.02 & -0.35 & 0.38 & 0.22 & -0.13 & -0.17 & 0.04 \\
& $(0.23)$ & $(1.61)$ & $(0.68)$ & $(1.16)$ & $(0.81)$ & $(0.32)$ & $(0.05)$ \\
Dem. & $-1.05^{*}$ & 0.37 & 0.82 & 0.11 & 0.005 & 0.15 & -0.39 \\
& $(2.85)$ & $(1.25)$ & $(1.04)$ & $(0.53)$ & $(0.05)$ & $(0.21)$ & $(0.49)$ \\
\hline R-squared & 0.48 & 0.14 & 0.14 & 0.15 & 0.07 & 0.08 & 0.06 \\
Observations & 38 & 38 & 38 & 38 & 38 & 38 & 38 \\
\hline Dep. Var.: & Growth & Indirect & Unemp. & Morale & Business & Self-Emp. & PIT \\
\hline Regressor & & & & & & & \\
\hline Capital & $2.05^{*}$ & $-0.79^{* * *}$ & -1.52 & 0.40 & -0.04 & 0.31 & -0.40 \\
& $(3.17)$ & $(1.78)$ & $(1.48)$ & $(1.43)$ & $(0.58)$ & $(1.14)$ & $(0.79)$ \\
Gov & -0.02 & -0.07 & 0.12 & -0.03 & -0.02 & 0.03 & -0.02 \\
& $(0.31)$ & $(1.15)$ & $(1.29)$ & $(0.62)$ & $(1.35)$ & $(0.89)$ & $(0.09)$ \\
GDP & $0.03^{* *}$ & -0.009 & -0.02 & $-0.02^{* *}$ & -0.0005 & 0.005 & -0.01 \\
& $(2.10)$ & $(1.09)$ & $(0.50)$ & $(2.29)$ & $(0.03)$ & $(1.16)$ & $(0.46)$ \\
Bur. & -0.21 & -0.46 & 0.48 & 0.26 & -0.04 & -0.07 & 0.03 \\
& $(0.46)$ & $(1.62)$ & $(0.68)$ & $(1.22)$ & $(0.83)$ & $(0.32)$ & $(0.04)$ \\
Dem. & $-1.45^{* *}$ & 0.52 & 1.04 & 0.17 & 0.01 & 0.07 & -0.37 \\
& $(2.07)$ & $(1.37)$ & $(1.10)$ & $(0.73)$ & $(0.22)$ & $(0.26)$ & $(0.58)$ \\
\hline R-squared & 0.32 & 0.16 & 0.14 & 0.21 & 0.07 & 0.08 & 0.05 \\
Observations & 38 & 38 & 38 & 38 & 38 & 38 & 38 \\
\hline
\end{tabular}

The top panel uses driving forces from the MIMIC approach whereas the bottom panel uses the ones from the DGE. Absolute values of robust $t$-statistics are reported in parentheses. *, **, *** denote 1, 5 and $10 \%$ confidence levels, respectively. In all regressions a constant is also included but not reported. Capital, gov, GDP, Bur. and Dem. Stand for the capital-output ratio, government spending as \% of GDP, GDP per-capita, Bureaucratic Quality and Democratic Accountability indices, respectively.

Table 6 presents the outputs of these regressions. The top panel uses driving forces from the MIMIC approach whereas the bottom panel uses the ones from the DGE. Table 6 illustrates several interesting facts. According to the results presented in the top panel, a larger capital-output ratio is associated with a higher contribution of the growth of GDP per-capita and tax morale to shadow economies as measured by the MIMIC approach,

\footnotetext{
${ }^{[16]}$ Capital-output ratio is calculated using data from Penn World Tables 8.1 (PWT) along with the perpetual inventory method. Similarly, we have obtained government spending (as \% of GDP) from PWT: GDP per-capita is obtained from WDI and finally the two institutional quality indices, i.e. bureaucratic quality and democratic accountability indices, are extracted from the International Country Risk Guide of the PRS Group.
} 
whereas a higher democratic accountability index (GDP per-capita) is associated with a lower contribution of the growth of GDP per-capita (tax morale) to shadow economies. Next, according to the results presented in the bottom panel, a larger capital-output ratio and GDP per-capita is associated with a larger contribution, whereas a larger democratic accountability index is associated with a smaller contribution of the growth of GDP per-capita to shadow economies. Similarly, a larger capital-output ratio is associated with a smaller contribution of the indirect taxes, and a larger GDP per-capita with a smaller contribution of tax morale to shadow economies. It is especially worth noting the contribution of the capital-output ratio, as it plays a key role in the DGE estimates. The DGE model assumes that the shadow economy does not employ physical capital in production. Therefore, with physical capital accumulation over time, which is one the major sources of GDP growth, the size of the shadow economy tends to decrease. ${ }^{[17]}$ All these results indicate that the differences in the relative contributions of the driving forces are systematic and correlated with certain macroeconomic and institutional characteristics of national economies.

\section{Summary and Conclusions}

In this paper we have compared the level and the driving forces of the shadow economies in 38 OECD countries using two different estimation methodologies. The first estimation procedure is the multiple-indicators-multiple-causes (MIMIC) approach, which is based on an estimation of a structural equation model. The second estimation procedure is based on a two-sector dynamic general equilibrium (DGE) model, which was developed by Elgin and Oztunali (2012). For both models we got estimates over the period 1999 to 2010 for 38 OECD countries. The driving forces obtained using the MIMIC model show that the personal income tax (13.8\%), indirect taxes $(14.1 \%)$, tax morale (14.5\%), unemployment (14.7\%), self-employment (14.5\%), GDP growth (14.3\%) and the business freedom index $(14.2 \%)$ contribute more or less evenly to the shadow economies. In contrast to this result, according to the estimates constructed using the DGE model (the driving forces of the shadow economy), the growth of GDP per capita has by far the largest effect $(24.7 \%)$, followed by indirect taxes $(18.5 \%)$, unemployment $(18.3 \%)$, tax morale $(17.1 \%)$, personal income tax $(11.2 \%)$, self-employment $(5.8 \%)$ and the business freedom index (4.3\%). Surely one should accept that all these estimates lie within a confidence interval.

Considering the size of the shadow economy using the two models, the size follows a similar pattern. There is more or less a steady decline from the year 1999 up to the year 2008 and with the MIMIC estimates, then an increase, and then a further decline. With the DGE estimates there is a decline up to the year 2010.

${ }^{[17]}$ This is also one of the main reasons (albeit not the only one) why the in the DGE estimates, the general trend of informality is decreasing over time for most countries from 1950 to 2010. 
What type of conclusions can we draw from this comparison?

The size of the shadow economies using these two approaches is very similar and its trend (a declining one over the period 1999 to 2010) is also reached by the two estimation procedures. The MIMIC estimation procedure is somewhat more sensitive to cyclical fluctuations because the shadow economy increases by the MIMIC estimations in the years 2008 and 2009 for the 38 countries.

An interesting result is the similar pattern of the size of the shadow economy but a quite different pattern of the driving forces of the shadow economy using the two estimation methods.

In order to detect the reasons for these differences in the driving forces a more careful study for single OECD countries is necessary.

\section{References}

Bajada, C. and Schneider F. (2005). Size, Causes and Consequences of the Underground Economy: An International Perspective. Aldershot (GB): Ashgate Publishing Company.

Bollen, K.A. (1989). Structural Equations with Latent Variables. New York: Wiley.

Breusch, T. (2005a). The Canadian Underground Economy: An Examination of Giles and Tedds. Canadian Tax Journal, 53(2): 367-391.

------, (2005b). "Estimating the Underground Economy, Using MIMIC Models.” Working Paper. National University of Australia, Canberra, Australia.

Buehn, A. and Schneider, F. (2012). "Shadow Economies around the World: Novel Insights, Accepted Knowledge, and New Estimates," International Tax and Public Finance, 19: 139-171.

(2013). "Size and Development of Tax Evasion in 38 OECD Countries: What Do We (not) Know," Johannes Kepler University Working Paper.

Buehn, A., Karmann, A., and Schneider, F. (2009). Shadow Economy and Do-it-yourself Activities: The German Case," Journal of Institutional and Theoretical Economics, 164(4): 701-722.

Busato, F. and Chiarini, B. (2004). "Market and Underground Activities in a Two-sector Dynamic Equilibrium Model,” Economic Theory, 23(4): 863-861.

Byrne, B.M. (1998). Structural Equation Modelling with LISREL, PRELIS and SIMPLIS: Basic Concepts, Applications and Programming. Mahwah, NJ: Lawrence Erlbaum Associates.

Chatterjee, S., Chaudhury K., and Schneider, F. (2006). "The Size and Development of the Indian Shadow Economy and a Comparison with 18 other Asian Countries: An Empirical Investigation," Forthcoming in the Journal of Development Economics.

Cziraky, D. (2004). "LISREL 8.54: A Program for Structural Equation Modelling with Latent Variables," Journal of Applied Econometrics, 19: 135-141.

------, (2005). “A Unifying Statistical Framework for Dynamic Structural Equation Models with Latent Variables.” Available [online at]: http://stats.lse.ac.uk/ciraki/framework.pdf.

Dell'Anno, R. (2003). "Estimating the Shadow Economy in Italy: A Structural Equation Approach," Discussion Paper, Department of Economics and Statistics, University of Salerno. 
Dell'Anno, R. and Schneider, F. (2009). "A Complex Approach to Estimate the Shadow Economy: The Structural Equation Modelling," in M. Faggini and T. Lux (eds.), Coping with the Complexity of Economics: 110-130. Heidelberg: Springer Publishing Company.

Elgin, C. (2012). “Cyclicality of Shadow Economy,” Economic Papers, 31 (4): 478-490.

Elgin, C. and Oztunali, O. (2012). "Shadow Economies around the World: Model Based Estimates," Bogazici University Working Papers 2012-05.

Feld, L.P. and Schneider, F. (2010). "Survey on the Shadow Economy and Undeclared Earnings in OECD Countries," German Economic Review 11(2): 109-149.

Frey, B.S. and Weck H.H. (1983). "Estimating the Shadow Economy: A Naive Approach," Oxford Economic Papers, 35: 23-44.

Giles, David, E.A. (1999a). "Measuring the Hidden Economy: Implications for Econometric Modelling," The Economic Journal, 109(456): 370-380.

-----, (1999b): "Modelling the Hidden Economy in the Tax-Gap in New Zealand," Empirical Economics, 24(4): 621-640.

-----, (1999c). "The Rise and Fall of the New Zealand Underground Economy: Are the Reasons Symmetric?," Applied Economic Letters, 6: 185-189.

Giles, David, E.A. and Tedds, L.M. (2002a). "Taxes and the Canadian Underground Economy," Canadian Tax Paper No. 106, Canadian Tax Foundation, Toronto/Ontario.

------, (2002b). “Response,” Canadian Tax Journal, 50(5): 1662-1667

Giles, David, E.A., Tedds, L.M., and Werkneh, G. (2002). "The Canadian Underground and Measured Economies," Applied Economics, 34(4): 2347-2352.

Hayduk, L.A. (1987). Structural Equation Modelling with LISREL. Essentials and Advances. London: The Johns Hopkins University Press.

Hoyle, R.H. (ed.) (1995). Structural Equation Modeling: Concepts, Issues, and Applications. Thousand Oaks, CA: Sage Publications.

Ihrig, J. and Moe, K. (2004). "Lurking in the Shadows: The Informal Sector and Government Policy," Journal of Development Economics, 73: 541-77.

Maruyama, G.M. (1997). Basic of Structural Equation Modeling. Thousand Oaks, CA: Sage Publications. Muthen, B.O. (2002). "Beyond SEM: General Latent Variable Modeling," Behaviormetrika, 29: 81-117. Pickhardt, M. and Sardà Pons, J. (2006). "Size and Scope of the Shadow Economy in Germany," Applied Economics, 38(4): 1707-1713.

Roca, J.C.C., Moreno, C.D., and Sanchez, J.E.G. (2001). "Underground Economy and Aggregate Fluctuations," Spanish Economic Review, 31: 41-53.

Schneider, F. (2005). "Shadow Economies around the World: What Do We Really Know?," European Journal of Political Economy, 21(3): 598-642.

-----, (2007): "Shadow Economies and Corruption all Over the World: New Estimates for 145 Countries," Economics, 1: 1-66.

Schneider, F. (eds.), (2011). Handbook on the Shadow Economy, Cheltenham (UK): Edward Elgar Publishing Company.

-----, (2013) "Size and Development of the Shadow Economy of 31 European and 5 other OECD Countries from 2003 to 2013: A Further Decline," Discussion Paper, Department of Economics, University of Linz, Linz, Austria. 
Schneider, F. and Enste, D. (2000). „Shadow Economies: Size, Causes and Consequences,” Journal of Economic Literature, 38(1): 73-110.

Schneider, F. and Williams, C.C. (2013). “The Shadow Economy," IEA (The Institute of Economic Affairs), London.

Schneider, F., Buehn, A., and Montenegro, C.E. (2010). "Shadow Economies All over the World: New Estimates for 162 Countries from 1999 to 2007," (Revised Version): 9-13. World Bank Discussion Paper.

Thomas, J.J. (1999). "Quantifying the Black Economy: Measurement without Theory Yet Again?," The Economic Journal, 109(456): 381-389.

Weck, H.H. (1983). Schattenwirtschaft: Eine Möglichkeit zur Einschränkung der öffentlichen Verwaltung? Eine ökonomische Analyse, Bern/Frankfurt: Lang. 